\title{
Оцінка ефективності лікування паціентів із перилімфатичними фістулами різного генезу
}

\begin{abstract}
Мета роботи: провести оцінку ефективності лікування пацієнтів із спонтанними та набутими ПЛФ при ХГСО з холестеатомою шляхом дослідження клініко-аудіологічних результатів після використання мініінвазивних мікрохірургічних методів хірургічного лікування з оптимальною комбінованою візуалізацією ураженої ділянки.

Матеріали і методи. Обстежено 33 пацієнти з ПЛФ різного генезу віком від 20 до 62 років, які знаходилися на лікуванні у відділі мікрохірургії вуха. Пацієнти були розподілені на групи залежно від етіологічного чинника виникнення ПЛФ. I групу склали пацієнти зі спонтанною ПЛФ (n=13), II групу - пацієнти з холестеатомною формою ХГСО та набутою ПЛФ $(\mathrm{n}=20)$. Всім пацієнтам проводили: отомікроскопію, тональну порогову аудіометрію, імпедансометрію, комп’ютерну томографію скроневих кісток (КТ) та магнітно-резонансну томографію головного мозку (МРТ).

Результати оцінювали до та після лікування, через 6 місяців після операційного лікування, використовуючи міжнародну класифікацію порушень слуху за даними ВООЗ.

Всім пацієнтам були проведені операційні втручання - мініінвазивна тимпанотомія з використанням комбінованої мікроскопічної та ендоскопічної візуалізації ділянки ПЛФ та пластики ділянки фістули пломбувальним матеріалом.

Статистичну обробку отриманих результатів проводили із використанням ліцензійного пакета “MSExcel 2010" та “Statisticav8.0” з використанням відповідних методів статистичної обробки даних.

Результати досліджень та їх обговорення. У пацієнтів обох дослідних груп визначалось зменшення порогів сприйняття звуків по КП на всіх дослідних частотах в терміни 6 місяців після хірургічного лікування.

У пацієнтів І групи до операційного лікування пороги сприйняття звуків по КП визначалися від 29,2 до 58,8 дБ, а у пацієнтів II складали від 6,3 до 25,0 дБ.

У терміни 6 місяців після операції визначалася тенденція до зменшення порогів сприйняття звуків по КП у пацієнтів обох груп, а у пацієнтів ІІ групи - достовірне зменшення вищевказаних порогів на всіх дослідних частотах від 4,5 до 21,8 дБ.

Зменшення порогів сприйняття ПП визначалося у всіх дослідних групах пацієнтів, з більш вираженими значеннями на частотах 500 Гц - 1 кГц у пацієнтів II групи та з тенденцією до зменшення на всіх дослідних частотах у пацієнтів I групи.

Також встановлено достовірне зменшення КПІ у пацієнтів обох дослідних групах через 6 місяців після проведеного хірургічного лікування, що вказує на функціональну ефективність проведеної мініінвазивної тимпанотомії з закриттям ПЛФ із використанням оптимальної комбінованої візуалізації.
\end{abstract}

Ключові слова: перилімфатична фістула; кісткова провідність; повітряна провідність; кістково-повітряний інтервал; мініінвазивна тимпанотомія; ідіопатична сенсоневральна приглухуватість; холестеатома.

Постановка проблеми і аналіз останніх досліджень та публікацій. Клініко-діагностичні підходи до виявлення та лікування перилімфатичної фістули (ПЛФ) впродовж останніх п’яти десятиріч залишаються спірними в сучасній отоларингології. Більшість науковців дотримується поглядів щодо виявлення клінічних симптомів її прояву за відсутності об’єктивних тестів для діагностики та першочерговості (або необхідності) проведення мініінвазивної діагностичної тимпанотомії [1].

ПЛФ - це вроджений або набутий дефект в ділянках лабіринтних вікон на межі середнього й внутрішнього вуха, що супроводжується утворенням стійкого співвустя та призводить до порушення гідродинаміки внутрішнього вуха зі зміною співвідношення між рівнем перилімфи в завитці та напівколових каналах [2].

Наявність перилімфатичної фістули різного генезу в пацієнтів супроводжується такими інвалідизуючими станами, як головокружіння, напа- ди запаморочення, невпевненість при ходьбі, нудотою, блювання, розвитком прогресуючої, іноді флюктуючої приглухуватості.

У діагностиці ПЛФ першочергового значення надають анамнестичним даним (виявленню можливого етіологічного фактора). Патогномонічними симптомами є однобічне зниження слуху різного характеру, головокружіння, нудота, виражений вушний шум або дзвін; позитивна фістульна проба (проба Тулліо) - посилення головокружіння при впливі гучних звуків на уражене вухо.

Перилімфатичні фістули за характером виникнення поділяються на ідіопатичні (спонтанні) та набуті.

Спонтанна ПЛФ вважається одним з етіологічних факторів виникнення раптової ідіопатичної сенсоневральної приглухуватості або глухоти та завжди супроводжується головокружінням [3].

Набуті ПЛФ частіше виникають внаслідок впливу травмуючого агенту: прямого або опосередкованого. 
Травматична ПЛФ виникає після черепномозкових травм (ЧМТ), переломів піраміди скроневої кістки (СК), прямих ударів по вуху, акубаротравми, при чханні, сморканні, піднятті тяжкого, хірургічних втручань і т. п. [3].

Згідно з класифікацією Glasscock (1982) [4] відносно етіології травматичного агенту ушкодження, травми поділяються на внутрішні, що спричиняють експлозивний механізм виникнення ПЛФ та виникають безпосередньо під час інтенсивного фізичного навантаження, кашлю, сміху, чханні або ж внаслідок підвищення внутрішньочерепного тиску (пухлина) та зовнішній механізм - імплозивний механізм (закриті та відкриті черепно-мозкові травми; акустична травма; баротравма; форсована проба Вальсальви: “хлистова” травма) [4].

Також ПЛФ можуть утворюватися внаслідок деструктивного каріонекротичного процесу або холестеатомного процесу в пацієнтів із хронічним гнійним середнім отитом (ХГСО) [5]. Частота виникнення ПЛФ при хронічному гнійному середньому отиті з холестеатомою складає від 5 до 20 \% [5]. ПЛФ при ХГСО становлять значний ризик щодо виникнення ускладнень (лабіринтиту, комбіновані і сенсоневральні порушення слуху та ін.). У 80 \% випадках передопераційна СКТ скроневих кісток дозволяє визначити деструкцію з наявністю ПЛФ [5].

Ідентифікація ПЛФ, терміни визначення та своєчасність проведення етіопатогенетичного лікування є основними підходами в протоколі лікування пацієнтів з даною патологією.

Мета роботи - провести оцінку ефективності лікування пацієнтів із спонтанними та набутими ПЛФ при ХГСО з холестеатомою шляхом дослідження клініко-аудіологічних результатів після використання мініінвазивних мікрохірургічних методів операційного лікування з оптимальною комбінованою візуалізацією ураженої ділянки.

Матеріали і методи. Для досягнення поставленої мети обстежено 33 пацієнти з ПЛФ різного генезу віком від 20 до 62 років, які знаходилися на лікуванні у відділі мікрохірургії вуха. Пацієнти були розподілені на групи залежно від етіологічного чинника виникнення ПЛФ. І групу склали пацієнти зі спонтанною ПЛФ (n=13), II групу - пацієнти з холестеатомною формою ХГСО та набутою ПЛФ (n=20).

Всім пацієнтам, окрім оцінки соматичного статусу і ЛОР огляду, рутинним способом проводили спеціальні методи дослідження: отомікроскопію, тональну порогову аудіометрію, імпедансометрію, комп'ютерну томографію скроневих кісток (КТ) та магнітно-резонансну томографію головного мозку (МРТ).
Аудіологічне обстеження слухової функції проводили на аудіометрі «ITERA» (Данія) за загальноприйнятою схемою за допомогою порогових тональних та мовних тестів. Результати оцінювали до та після лікування, через 6 місяців після операційного лікування, використовуючи міжнародну класифікацію порушень слуху за даними ВООЗ [6].

Комп'ютерну томографію виконували на комп’ютерному томографі Philips Brilliance 64, 3 товщиною зрізу 0.67 мм, з реконструкцією у сагітальній та корональній площинах

Всім пацієнтам були проведені операційні втручання - мініінвазивна тимпанотомія з використанням комбінованої мікроскопічної та ендоскопічної візуалізації ділянки ПЛФ та пластики ділянки фістули пломбувальним матеріалом (сполучнотканинний, жировий клапоть, кістковий пил, фасція скроневого м'яза, автохрящ).

Критеріями включення в дослідження були наявність у пацієнтів скарг на зниження слуху різного характеру, головокружіння різного ступеня, оторею у пацієнтів з ХГСО, анамнестичні дані, ознаки деструктивних змін у ділянці лабіринту у пацієнтів із холестеатомними формами ХГСО, наявність повітря в присінку в пацієнтів із спонтанними ПЛФ.

Статистичну обробку отриманих результатів проводили із використанням ліцензійного пакета "MSExcel 2010" та "Statisticav-8.0" $з$ використанням відповідних методів статистичної обробки даних. При значеннях $\mathrm{p}<0,05$ відмінності вважали достовірними.

Результати досліджень та їх обговорення. 1 групу склали 13 пацієнтів зі спонтанною ПЛФ (після впливу травмуючого фактора в анамнезі (черепно-мозкова травма, політравма, як наслідок ДТП, баротравма). 2 групу склали 20 пацієнтів 3 набутими ПЛФ (при наявності ХГСО з холестеатомою та грануляціями і вираженим каріонекротичним процесом в ділянці овального вікна, верхнього напівколового каналу та латерального напівколового каналу).

Домінуючими скаргами у пацієнтів обох груп були вестибулярні порушення (головокружіння, невпевненість ходи), зниження слуху різного характеру та наявність шуму (табл. 1 ).

У 19 (69,7 \%) пацієнтів визначалася позитивна фістульна проба. Спонтанний ністагм у бік неураженого вуха з ознаками гіпорефлексії ністагмової реакції мали місце у всіх хворих.

Визначення локалізації ПЛФ у пацієнтів обох груп здійснювалось за даними КТ скроневих кісток (табл. 2). 
Таблиця 1. Клінічні ознаки в пацієнтів дослідних груп

\begin{tabular}{||c|c|c||}
\hline \multirow{2}{*}{\multicolumn{1}{|c|}{ Клінічні ознаки }} & \multicolumn{2}{c||}{ Дослідні групи } \\
\cline { 2 - 3 } & I група, (n=13) & $10(50 \%)$ \\
\hline Головокружіння & $13(100 \%)$ & 7 \\
\hline Позитивна фістульна проба & $11(84,6 \%)$ & $14(70 \%)$ \\
\hline Кондуктивна приглухуватість & 1 & 6 \\
\hline Змішана приглухуватість & $12(92,3 \%)$ & 8 \\
\hline Шум & 6 & $(\mathrm{n}=20)$ \\
\hline \hline
\end{tabular}

Таблиця 2. Локалізація перилімфатичної фрістули

\begin{tabular}{||l|c|c||}
\hline \multirow{2}{*}{\multicolumn{1}{|c|}{ КТ ознаки }} & \multicolumn{2}{c||}{ Дослідні групи } \\
\cline { 2 - 3 } & I група, $\mathrm{n}=13$ & II група, $\mathrm{n}=20$ \\
\hline Розрив мембрани круглого вікна & 5 (38,5 \%) & 1 \\
\hline Повітря в присінку & 4 & 3 \\
\hline Дефект (фістула) в ділянці овального вікна & 4 & 3 \\
\hline Дегісценції та фістула ВПК & 3 & 14 (70 \%) \\
\hline Фістула ЛПК & & 2 \\
\hline \hline
\end{tabular}

За даними КТ скроневих кісток деструкція в ділянці лабіринтних вікон визначалася у 12 пацієнтів (36 \%): в ділянці овального вікна в 4 випадках у пацієнтів 1 групи та у 3 - з 2 групи, в ділянці круглого вікна - у 5 пацієнтів 1 групи. Повітря в присінку визначалося у 5 пацієнтів 1 групи (рис. 1).

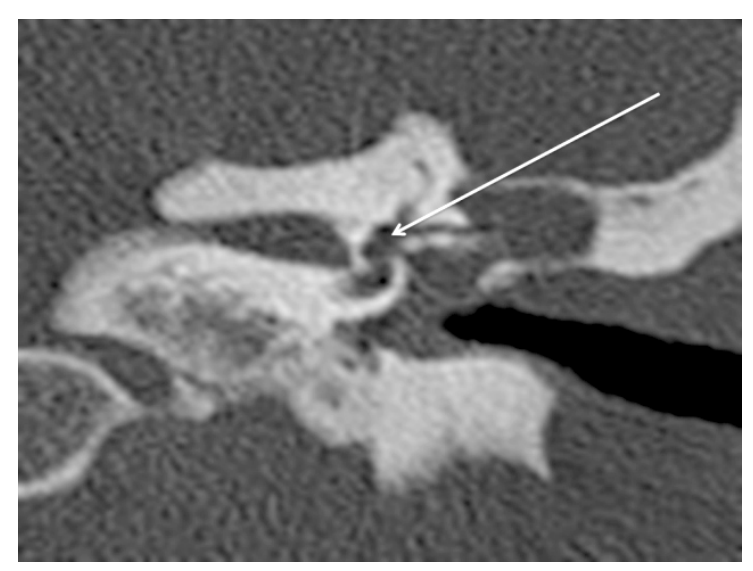

Рис. 1. КТ лівої скроневої кістки пацієнта Ш. 3 ПЛФ. Повітряний пухирець в присінку.
У пацієнтів 2 групи фістулу в ділянці горизонтального (латерального) півколового каналу - у 14 (70 \%) пацієнтів, в ділянці верхнього (сагітального) півколового каналу у 3 пацієнтів, в ділянці підніжної пластинки стремена - у 3 пацієнтів (рис. 2).

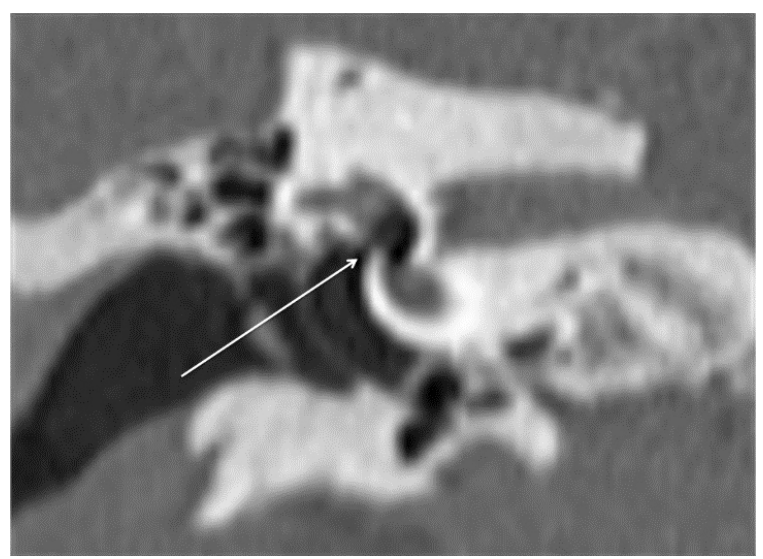

Рис. 2. Пацієнт П. - перилімфатична фістула в ділянці овального вікна при наявності холестеатоми в барабанній порожнині та аттику. 
Основним підходом в лікуванні пацієнтів I групи (зі спонтанними ПЛФ) було проведення мініінвазивної тимпанотомії з комбінованою мікроскопічно-ендоскопічною візуалізацією (ендоскоп $30^{\circ}$ ). Пластика і закриття ПЛФ здійснювались вільним автосполучнотканинним клаптем та жельфоамом, просякненим розчином дексаметазону.

При лікуванні пацієнтів II групи (ХГСО з холестеатомою) основними підходами в лікування були проведення сануючого етапу операції, тимпанопластики з наступним закриттям ПЛФ.

Відкритий варіант тимпанопластики $3-14$ (70 \%) пацієнтам, закритий варіант тимпанопластики - у 2 пацієнтів, ендауральна тимпанопластика - 2 (12,5 \%) пацієнтам, субтотальна петрозектомія - в 2 клінічних випадках.

При виборі матеріалу для пластики ПЛФ враховували її локалізацію. На першому етапі проводилася санація патологічного осередка (холестеатома, грануляції, ділянки каріонекротичного процесу). Видалення холестеатомного матриксу з ділянки ПЛФ здійснювалося на заключному етапі операції, безпосередньо перед проведенням ії̈ пластики.

Функціональні результати операційних втручань при ПЛФ оцінювалися за даними аудіологічного дослідження слухової функції. Визначалися пороги сприйняття за ПП, КП та визначалися величини кістково-повітряного інтервалу (KПI) на основних частотах: 0,$5 ; 1 ; 2 ; 4$ кГц до та в терміни 6 місяців після операційного лікування з викорис- танням комбінованої мікроскопічно-ендоскопічною візуалізації (див. табл. 1-3).

За даними таблиці 3, у пацієнтів обох дослідних груп визначалось зменшення порогів сприйняття звуків по КП на всіх дослідних частотах у терміни 6 місяців після хірургічного лікування. Однак у пацієнтів I групи до операційного лікування пороги сприйняття звуків по КП визначалися від 29,2,0 до 58,8 дБ, а у пацієнтів II складали від 6,3 до 25,0 дБ. Це вказує на вищий ступінь зниження слуху по кістковій провідності (сенсоневральні ураження) у пацієнтів I групи. В терміни 6 місяців після операції визначалася тенденція до зменшення порогів сприйняття звуків по КП у пацієнтів обох груп, а у пацієнтів II групи - достовірне зменшення вищевказаних порогів на всіх дослідних частотах від 4,5 до 21,8 дБ.

За даними таблиці 4 визначається зменшення порогів сприйняття ПП звуків у всіх дослідних групах пацієнтів із більш вираженими значеннями на частотах 500 - 1 кГц у пацієнтів II групи та з тенденцією до зменшення на всіх досліджуваних частотах у пацієнтів I групи.

При аналізі даних таблиці 5 встановлено достовірне зменшення КПІ у пацієнтів обох дослідних групах через 6 місяців після проведеного хірургічного лікування.

За результатами дослідження слухової функції у пацієнтів I групи збільшення порогів кістковопроведених звуків більше 55 дБ до операції визна-

Таблиця 3. Середні величини порогів сприйняття звуків по кістковій провідності у дБ за даними тональної порогової аудіометрії у хворих I та II дослідних груп із перилімсратичною фрістулою різного генезу до та після хірургічного лікування

\begin{tabular}{|c|c|c|c|c|c|}
\hline \multicolumn{2}{|c|}{ Групи } & $\begin{array}{c}\text { I група (спонтанна), } \\
\text { (n=13) }\end{array}$ & $\begin{array}{c}\mathrm{pI}, \\
(\text { со - після) }\end{array}$ & $\begin{array}{c}\text { II група, } \\
\text { (наб }\end{array}$ & $\begin{array}{c}\text { pII, } \\
\text { (до - після) }\end{array}$ \\
\hline \multirow[t]{2}{*}{500 Гц } & до & $29,2 \pm 6,8$ & \multirow[t]{2}{*}{0,166} & $6,3 \pm 1,4$ & \multirow[t]{2}{*}{0,129} \\
\hline & після & $21,9 \pm 7,0$ & & $4,5 \pm 1,1$ & \\
\hline \multirow[t]{2}{*}{$1 \mathrm{k} Г ц$} & до & $51,2 \pm 13,0$ & \multirow[t]{2}{*}{$0,019 *$} & $11,3 \pm 2,2$ & \multirow[t]{2}{*}{0,144} \\
\hline & після & $28,8 \pm 7,7$ & & $8,8 \pm 2,2$ & \\
\hline \multirow[t]{2}{*}{ 2кГц } & до & $56,2 \pm 13,3$ & \multirow[t]{2}{*}{$0,039 *$} & $18,8 \pm 2,5$ & \multirow[t]{2}{*}{$0,002 *$} \\
\hline & після & $31,9 \pm 6,5$ & & $14,5 \pm 2,4$ & \\
\hline \multirow[t]{2}{*}{$4 к Г ц$} & до & $58,8 \pm 13,2$ & \multirow[t]{2}{*}{$0,022 *$} & $25,0 \pm 4,4$ & \multirow[t]{2}{*}{0,199} \\
\hline & після & $31,2 \pm 7,1$ & & $21,8 \pm 3,9$ & \\
\hline \multirow{2}{*}{$\begin{array}{l}\text { Середня } \\
\text { (дб) }\end{array}$} & до & $48,8 \pm 11,3$ & \multirow[t]{2}{*}{$0,024^{*}$} & $15,3 \pm 2,0$ & \multirow[t]{2}{*}{$0,002 *$} \\
\hline & після & $28,4 \pm 6,7$ & & $12,4 \pm 1,9$ & \\
\hline
\end{tabular}

Примітка. * - p<0,05 - статистично значуща різниця показників порогів сприйняття до та після лікування (тест Вілкоксона). 
Таблиця 4. Середні величини порогів сприйняття звуків по повітряній провідності в дБ за даними тональної порогової аудіометрії у хворих I та II дослідних груп із перилімфатичною фрістулою різного генезу до та після хірургічного лікування

\begin{tabular}{|c|c|c|c|c|c|}
\hline \multicolumn{2}{|c|}{ Групи } & I група, (n=13) & pI, (до - після) & II група, (n=20) & pII, (до - після) \\
\hline \multirow[t]{2}{*}{500 Гц } & до & $58,8 \pm 10,2$ & \multirow[t]{2}{*}{$0,007 *$} & $43,4 \pm 2,5$ & \multirow[t]{2}{*}{$0,0001^{*}$} \\
\hline & після & $36,1 \pm 6,3$ & & $34,0 \pm 2,7$ & \\
\hline \multirow[t]{2}{*}{$1 к Г ц$} & до & $61,9 \pm 10,3$ & \multirow[t]{2}{*}{$0,017^{*}$} & $45,6 \pm 3,1$ & \multirow[t]{2}{*}{$0,008^{*}$} \\
\hline & після & $40,0 \pm 6,3$ & & $39,3 \pm 3,3$ & \\
\hline \multirow[t]{2}{*}{$2 к Г ц$} & до & $59,6 \pm 9,6$ & \multirow[t]{2}{*}{$0,008 *$} & $39,5 \pm 9,6$ & \multirow[t]{2}{*}{$0,031^{*}$} \\
\hline & після & $42,3 \pm 6,1$ & & $33,9 \pm 3,1$ & \\
\hline \multirow[t]{2}{*}{$4 к Г ц$} & до & $70,0 \pm 8,1$ & \multirow[t]{2}{*}{$0,029 *$} & $55,3 \pm 3,6$ & \multirow[t]{2}{*}{0,247} \\
\hline & після & $52,3 \pm 7,2$ & & $51,5 \pm 4,6$ & \\
\hline \multirow{2}{*}{$\begin{array}{l}\text { Середня } \\
\text { (дБ) }\end{array}$} & до & $62,6 \pm 9,1$ & \multirow[t]{2}{*}{$0,009 *$} & $45,9 \pm 2,2$ & \multirow[t]{2}{*}{$0,002^{*}$} \\
\hline & після & $42,7 \pm 5,6$ & & $39,7 \pm 2,9$ & \\
\hline
\end{tabular}

Примітка. * - p<0,05 - статистично значима різниця показників порогів сприйняття до та після лікування (тест Вілкоксона).

Таблиця 5. Середні величини кістково-повітряного інтервалу за даними тональної порогової аудіометрії у хворих I та II дослідних груп із перилімфатичною фрістулою різного генезу до та після хірургічного лікування

\begin{tabular}{||c|c|c|c||}
\hline Групи пацієнтів & До лікування, дБ & Після лікування, дБ & р \\
\hline I & $40,0 \pm 3,6$ & $25,2 \pm 2,3$ & $0,001^{*}$ \\
\hline II & $40,8 \pm 2,7$ & $32,5 \pm 2,6$ & $0,006^{*}$ \\
\hline \hline
\end{tabular}

Примітка. * - p<0,05 - статистично значима різниця показників КПІ до та після лікування (тест Вілкоксона)

чалося у 7 пацєінтів (53,8 \%), в терміни 6 місяців після КП на відповідному рівні визначалася лише у 3 пацієнтів. Зменшення величини КПІ до 10 дБ в терміни через 6 місяців після операції визначалася у 3 пацієнтів (23 \%), в межах 16-25 дБ у 8 пацієнтів (61,5 \%), що вказує на функціональну ефективність проведеної мінінназивної тимпанотомії 3 закриттям ПЛФ з використанням оптимальної комбінованої візуалізації. У 2 пацієнтів слух залишився без змін.

Дискусія. Термін “спонтанна ПЛФ” вперше запровадили в 1970 р. Stroud и Calcettera, беручи за основу дослідження чотирьох пацієнтів. ПЛФ називають спонтанною, коли відсутні очевидні причини її виникнення [1].

У 1992 році в журналі “Otolaryngology - Head and Neck Surgery” Shea [7] проголосив: “Міф спонтанної перилімфатичної фістули”, написав- ши наступне: Я не вірю, що існує таке поняття, як спонтанна перилімфатична фістула або ж вона настільки рідко зустрічається, що я, виконавши 36000 отологічних операцій за останні 39 років не діагностував такої жодного разу... Я вірю, що сучасний інтерес до спонтанних перилімфатичних фістул зародився у свідомості невеликої групи “дійсно переконаних”... що не існує жодних характерних ознак, симптомів чи тестів для діагностики спонтанних перилімфатичних фістул [7].

Уроджені аномалії розвитку внутрішнього вуха можуть бути однією з причин виникнення уродженої ПЛФ. Для розвитку ПЛФ найбільш сприятливими є розширений вестибулярний та кохлеарний акведук, уроджені аномалії будови стремена, аномалії Мондіні як з наявністю, так і відсутністю модіолюсу, а також анатомічні особливості будови в ділянці вікон лабіринту (аномалії розвитку, 
несприятливий кут нахилу вторинної мембрани круглого вікна, “плоска” ніша вікна завитки, відкрита fissula ante fenestrum - ділянка, яка розташована попереду овального та в нормі заповнена фіброзною тканиною) [8].

Інформативними в діагностиці вважаються променеві методи діагности - комп'ютерна томографія скроневих кісток та магнітно-резонансна томографія головного мозку. На КТ скроневих кісток характерною ознакою $є$ наявність пухирця повітря у присінку та анатомічного дефекту в ділянці лабіринтних вікон. МРТ головного мозку дає можливість встановлювати аномалії розвитку внутрішнього вуха, які супроводжуються гідродинамічними порушеннями.

Деколи можливе спонтанне закриття ПЛФ (має значення розмір ПЛФ і тиск перилімфи).

У підходах до медикаментозного лікування пріоритетними напрямками $є$ призначення антибіотиків, стероїдів, сечогінних препаратів та препаратів, що зменшують лікворопродукцію.

Пацієнтам показаний ліжковий режим з підвищеним положенням голови із виключенням будьяких фізичних навантажень.

Вперше повідомлення стосовно хірургічного лікування пацієнтів при підозрі на наявність ПЛФ зробив Goodhill V. та висвітив його у своїй роботі "Sudden Deafness and Round Window Rupture” у 1971 [9]. Виконання тимпанотомії із виявленням та подальшим закриттям ПЛФ не отримало значної підтримки у науковців того часу. Як пломбувальний матеріал використовували м'якотканинний пломбувальний матеріал.

У 2017 Prenzler [10] запропоновано використовувати діагностичну тимпанотомію у пацієнтів 3 раптовою СНГ без клінічних ознак наявності ПЛФ.

Отримані клінічні та функціональні результати дослідження пацієнтів із ПЛФ дослідних груп та підходу до мікрохірургічного лікування з комбінованою мікроскопічно-ендоскопічною візуалізацією демонструють ефективність в терміні 6 місяців після операції та потребують подальшого спостереження за пацієнтами для оцінки стабільності отриманих результатів у відділеному періоді.

Висновки. 1. Перманентними симптомами перилімфатичної фістули є зниження слуху та головокружіння різного ступеня вираження.

2. Своєчасне виявлення та закриття ПЛФ будьякого генезу та локалізації забезпечує усунення вестибулярних проявів до 66,7 \% випадків у досліджуваних групах пацієнтів та покращення слухової функції із зменшенням КПІ до 10 дБ в 25 \% випадків. КПІ в межах 11-30 дБ визначався у 11 (45,8 \%) пацієнтів. Лише в одному випадку пороги по КП та ПП залишилися без змін, незважаючи на проведення хірургічного закриття ПЛФ та пояснюється, на наш погляд, несвоєчасними термінами ï̈ визначення та, відповідно, термінів проведення операції.

3. Основним підходом у наданні високоспеціалізованої допомоги пацієнтам з ПЛФ залишається правильний відбір пацієнтів для хірургічного лікування та застосування раннього хірургічного мікроінвазивного втручання із комбінованою мікро- та ендоскопічною візуалізацією тонких структур та їх ушкоджень в ділянках лабіринтних вікон із одночасним закриттям руптур для запобігання можливим інвалідизуючим ускладненням та отримання стійких позитивних функціональних результатів.

4. Функціональні результати лікування у пацієнтів дослідних груп вказують на ефективність проведеного хірургічного лікування незалежно від етіологічного чинника розвитку перилімфатичної фістули та потребують динамічного спостереження за пацієнтами у віддаленому періоді.

\section{СПИСОК ЛІТЕРАТУРИ}

1. Hornibrook J. Fifty years of controversy / J. Hornibrook // ISRN Otolaryngol. - 2012.

2. Hoch S. Critical evaluation of round window membrane sealing in the treatment of idiopathic sudden unilateral hearing loss / S. Hoch, T .Vomhof, A. Teymoortash // Clin. Exp. Otorhinolaryngol. - 2015. - Vol. 8, No.1. - P. 20-25.

3. Effects of early surgical exploration in suspected barotraumatic perilymph fistulas / Ga Young Park, Ha Young Byun, II Joon Moon [et al.] // Clin. Exp. Otorhinolaryngol. - 2012. - Vol. 5, No. 2. - P. 74-80.

4. Jackson C. Glomus tumors. Diagnosis, classification, and management of large lesions / C. Jackson, M. Glasscock, P. F. Harris // Arch. Otolaryngol. - 1982. - Vol. 108, No. 7. - P. 401-410.

5. Clinical characteristics of patients with cochlear fistulas caused by chronic otitis media with cholesteatoma / Sang-Youp Lee, Jeon Seong, Young Eun Han [et al.] // J. Int. Adv. Otol. -

2020. - Vol. 16, No. 1. - P. 40-46.

6. World Health Organization. - [Electronic resource]. - Access mode : who.int/pbd/deafness/hearing_impairment_grades/en/

7. John J. The Myth of Spontaneous Perilymph Fistula / J. John, J. J. Shea // Otolaryngol. Head Neck Surg. - 1992. - Vol. 107, No. 5. - P. 613-616.

8. Kohut R. I. The histologic characteristics of the core of the fissula ante fenestrum / R. I. Kohut, R. Hinojosa, J. H. Ryu // Arch. Otolaryngol. Head Neck Surg. - 1995. - Vol. 121. P. 412-420.

9. Goodhill V. Sudden deafness and round window rupture / V. Goodhill // Laryngoscope. - 1997. - Vol. 107, No. 5. - P. 577-579. 10. The role of explorative tympanotomy in patients with sudden sensorineural hearing loss with and without perilymphatic fistula / N. Prenzler, B. Schwab, D. Kaplan, S. El-Saied // Am. J. Otolaryngol. - 2018. - Vol. 39, No. 1. - P. 46-49. 


\section{З ДОСВІДУ РОБОТИ}

\section{REFERENCES}

1. Hornibrook, J., (2012). Fifty years of controversy. ISRN Otolaryngol., 9

2. Hoch, S., Vomhof, T., Teymoortash, A. (2015). Critical evaluation of round window membrane sealing in the treatment of idiopathic sudden unilateral hearing loss. Clin. Exp. Otorhinolaryngol., 8 (1), 20-25.

3. Ga Young Park, Ha Young Byun, Joon Moon, II, Sung Hwa Hong, Yang-Sun Cho, Won-Ho Chung (2012). Effects of early surgical exploration in suspected barotraumatic perilymph fistulas. Clin. Exp. Otorhinolaryngol., 5 (2), 74-80.

4. Jackson, C., Glasscock, M., \& Harris, P.F. (1982). Glomus tumors. Diagnosis, classification, and management of large lesions. Arch. Otolaryngol., 108 (7), 401-410.

5. Woongsang Sunwoo, Sang-Youp Lee, Jeon Seong, Young Eun Han, Min-Hyun Park (2020). Clinical characteristics of

\section{O. V. SHERBUL, I. A. SREBNIAK, O. M. BORYSENKO, T. O. SHEVCHENKO}

A. I. Kolomiychenko Institute of Otolaryngology of the National Academy of Medical Sciences of Ukraine

\section{TREATMENT EFFECTIVENESS EVALUATION IN PATIENTS WITH PERILYMPHATIC FISTULAS}

The aim of the work: to evaluate the effectiveness of treatment in patients with spontaneous and acquired PLF with chronic suppurative otitis media and cholesteatoma by studying the clinical and audiological results after microsurgical treatment with optimal combined visualization of affected area.

Materials and Methods. 33 patients with different PLF etiology aged 20 to 62 were observed in ear microsurgery and otoneurosurgery department. Patients were divided into two groups of studies depending on the PLF etiology. Group I included patients with spontaneous PLF ( $\mathrm{n}=13$ ), group II - patients with chronic suppurative otitis media with cholesteatoma and acquired PLF ( $\mathrm{n}=20$ ).

All patients were examined by: otomicroscopy, pure tone audiogram, impedancemetry, computed tomography of the temporal bones (CT) and magnetic resonance image (MRI) of the brain.

All the results were assessed before and after drug treatment and 6 months after surgical treatment. Classification of hearing impairment grades by World Health Organization (WHO) were used.

All patients had undergone microtympanotomy under microscopic and endoscopic visualization of PLF region followed by its closure with plugging material.

The software used for statistical analysis were MSExcel 2010 and Statistica-8.0. All statistical analyses were considered significant where the $p$ value was less than 0.05 .

Results and Discussion. In both groups bone threshold decrease of all of the above frequencies was observed 6 months after surgery In patients of group I before surgery bone threshold was $29.2 \mathrm{~dB}$ to $58.8 \mathrm{~dB}$ while in patients of group II - between $6.3 \mathrm{~dB}$ to $25.0 \mathrm{~dB}$. 6 months after surgery tendency to decrease the bony threshold was observed in both groups, whereas in patients of group II - significant decrease of all of the above thresholds from 4.5 to $21.8 \mathrm{~dB}$.

Decrease of the air threshold was defined in both groups, with more significant values on $500 \mathrm{~Hz}$ to $1 \mathrm{kHz}$ in patients from group II with a tendency to decrease of all above mentioned frequencies in patents from group I.

A significant reduction of air-bone gap in patients from both groups 6 months after operative treatment were found. These data suggest functional effectiveness of microtympanotomy with PLF sealing using combined endoscopic and microscopic assistance.

Key words: perilymphatic fistula; bone conduction; air conduction; air-bone gap; microtympanotomy; idiopatic sensorineural hearing loss; cholesteatoma. 


\section{О. В. ШЕРБУЛ, И. А. СРЕБНЯК, О. Н. БОРИСЕНКО, Т. А. ШЕВЧЕНКО}

ГУ “Институт отоларингологии имени проф. А. И. Коломийченко НАМН Украины”

\section{ОЦЕНКА ЭФФЕКТИВНОСТИ ЛЕЧЕНИЯ ПАЦИЕНТОВ С ПЕРИЛИМФАТИЧЕСКИМИ ФИСТУЛАМИ РАЗНОГО ГЕНЕЗА}

Цель работы: провести оценку эффективности лечения пациентов со спонтанными и приобретенными ПЛФ при ХГСО с холестеатомой путем исследования клинико-аудиологических результатов после использования малоинвазивных микрохирургических методов оперативного лечения с оптимальной комбинированной визуализацией пораженного участка.

Материалы и методы. Обследовано 33 пациента с ПЛФ разного генеза в возрасте от 20 до 62 лет, которые находились на лечении в отделении микрохирургии уха. Пациенты были разделены на группы в зависимости от этиологического фактора возникновения ПЛФ. В І группу вошли пациенты со спонтанной ПЛФ (n=13), во II группу - пациенты с холестеатомной формой ХГСО и приобретенной ПЛФ (n=20).

Всем пациентам проводили: отомикроскопию, тональную пороговую аудиометрию, импедансометрию, компьютерную томографию височных костей (KT) и магнитно-резонансную томографию головного мозга (MPT).

Всем пациентам были проведены оперативные вмешательства - малоинвазивная тимпанотомия с использованием комбинированной микроскопической и эндоскопической визуализации области ПЛФ и пластики области фистулы пломбировочным материалом.

Статистический анализ полученных результатов проводили используя лицензионный пакет “MSExcel 2010” и “Statisticav-8.0” с использованием соответствующих методов статистической обработки данных. При значениях р<0,05 отличия считались достоверными.

Результаты исследований и их обсуждение. У пациентов обеих исследуемых групп определялось уменьшение порогов восприятия звуков по КП на всех исследуемых частотах в сроки 6 месяцев после хирургического лечения.

У пациентов I группы до хирургического лечения пороги восприятия звуков по КП определялись от 29,2,0 до 58,8 дБ, а у пациентов II группы составили от 6,3 до 25,0 дБ.

В сроке 6 месяцев после операции определялась тенденция к уменьшению порогов восприятия звуков по КП у пациентов обеих групп, а у пациентов II группы - достоверное уменьшение выше указанных порогов на всех исследуемых частотах от 4,5 до 21,8 дБ.

Уменьшение порогов восприятия ВП определялось во всех исследуемых группах пациентов, с более выраженными значениями на частотах 500 Гц - 1 кГц у пациентов II группы и с тенденцией к уменьшению на всех исследуемых частотах у пациентов І группы.

Также установлено достоверное уменьшение КВИ у пациентов обеих исследуемых групп через 6 месяцев после проведенного хирургического лечения, что указывает на функциональную эффективность проведенной малоинвазивной тимпанотомии с закрытием ПЛФ с использованием оптимальной комбинированной визуализации.

Ключевые слова: перилимфатическая фистула; костная проводимость; воздушная проводимость; костно-воздушный интервал; малоинвазивная тимпанотомия; идиопатическая сенсоневральная тугоухость; холестеатома. 